Indonesian Journal of
$\begin{gathered}\text { Mathematics and Natural Sciences Education } \\ \text { p-ISSN: 2721-172X } \\ \text { Vol. 1 No. 2 Th 2020; hal 74 - 2721-1746 } \\ \text { http://mass.iain-jember.ac.id }\end{gathered}$

\title{
Korelasi Tingkat Pemahaman Siswa Kelas XI IPA SMA pada Materi Sistem Pencernaan terhadap Perilaku Pemilihan Makanan
}

\author{
Lina Nur Amalina 1, Rosita Fitrah Dewi 2,* \\ ${ }^{1}$ MTs. Raudhatul Ulum. Malang, Indonesia, \\ ${ }^{2}$ Program Studi Tadris Biologi, IAIN Jember. Jember, Indonesia, \\ *E-mail: rositafitrah@gmail.com
}

\begin{abstract}
Abstrak
Tujuan dari penelitian ini adalah untuk mengetahui korelasi tingkat pemahaman materi sistem pencernaan terhadap perilaku pemilihan makanan. Penelitian ini merupakan penelitian kuantitatif dengan jenis penelitian korelasi. Populasi penelitian ini adalah siswa kelas XI IPA SMAN 3 Jember, pengambilan sampel dilakukan dengan menggunakan teknik random sampling. Berdasarkan hasil analisis data, diketahui bahwa tingkat pemahaman siswa pada materi pencernaan mayoritas dengan kriteria baik sebesar $92 \%$ dan perilaku pemilihan makanan siswa termasuk pada mayoritas kategori kuat, yaitu $86,2 \%$. Hasil analisis data menunjukkan bahwa terdapat korelasi antara tingkat pemahaman materi sistem pencernaan terhadap perilaku pemilihan makanan pada siswa kelas XI IPA SMAN 3 Jember sebesar 0,004 dengan tingkat keeratan 0,245 dan kategori korelasi rendah.
\end{abstract}

Kata Kunci: korelasi, perilaku pemilihan makanan, sistem pencernaan, tingkat pemahaman.

\section{PENDAHULUAN}

Kemampuan manusia menurut Taksonomi Bloom dibedakan manjadi 3 domain, yaitu kognititf, afektif dan psikomotorik. Salah satu kompetensi yang harus dimiliki oleh siswa dalam mempelajari ilmu pengetahuan, khususnya biologi adalah kemampuan kognitif. Perkembangan kemampuan kognitif pada dasarnya adalah suatu proses belajar yang mengikuti pola berpikir dan bekerja seseorang (Shaffer and Kipp, 2010). Berdasarkan Biological Science Curriculum Study (BSCS) lingkup keilmuan biologi terdiri atas objek biologi, problematika dalam biologi dan organisasi kehidupan (Dodge et. al: 2004).

Materi sistem pencernaan merupakan salah satu materi pada mata pelajaran Biologi yang diajarkan pada semester ganjil kelas XI SMA. Menurut Priyanto dan Lestari (2008) sistem pencernaan merupakan salah satu sistem dalam tubuh yang terdiri atas beberapa organ seperti mulut, faring, kerongkongan, lambung, usus halus, usus besar, dan anus. Pencernaan makanan dimulai dari makanan yang masuk melalui mulut hingga keluar melalui anus berupa ampas/feses. Pada prosesnya ada mekanis dan kimiawi. 
Sistem pencernaan mensuplai kebutuhan nutrisi yang dibutuhkan oleh tubuh untuk melakukan aktivitas sehari-hari. Dalam sistem pencernaan, tubuh memaksimalkan penyerapan nutrisi yang dicerna kemudian mengangkut zat-zat hasil penyerapan melalui peredaran darah ke sel untuk menghasilkan energi atau sebagai molekul pembangun dan pemelihara jaringan dan organ (Chalik, 2016).

Hasil observasi awal yang dilaksanakan pada bulan September Desember 2018 di SMAN 3 Jember menunjukkan bahwa di kantin dan koperasi siswa SMAN 3 Jember menjual beberapa makanan seperti gorengan dan juga olahan mie yang sering dibeli oleh siswa. Selain didalam area sekolah, ditemukan pula penjual cilok, cimol dan bakso yang berjualan di depan gerbang sekolah. Makanan berminyak tentunya sangat berbahaya jika dikonsumsi secara berlebihan. Makanan yang berminyak mengandung lemak jenuh yang dapat berakibat pada penyumbatan pembuluh darah dan bisa memicu penyakit stroke dan serangan jantung (Hanum, 2016). Observasi yang dilakukan didalam kelas pada saat apersepsi dan tanya jawab saat penjelasan materi sistem pencernaan menunjukkan bahwa beberapa siswa belum mengetahui penyebab beberapa penyakit pada sistem pencernaan seperti wasir, diare, dan sembelit. Akibat ketidaktahuan tersebut, siswa masih memilih makanan yang kurang sehat untuk dikonsumsi.

Pengetahuan memiliki hubungan dengan pola pikir dan perilaku. Pengetahuan diperoleh dari rekaman informasi yang diperoleh dari lingkungan.
Rekaman tersebut akan mem-bentuk pola pikir, yang dapat mempengaruhi perilaku seseorang (Makhmudah, 2016). Perilaku manusia terbentuk melalui proses dari adanya kebutuhan (needs), keinginan (longing), motivasi (motivation), sikap (attitude), dan niat (interest) (Dessler, 2010). Penelitian terdahulu oleh Hasmiati dan Jamilah (2016) mengungkapkan bahwa terdapat hubungan antara materi pengetahuan mikrobiologi dengan kegiatan atau kebiasaan sehari-hari. Mahasiswa yang telah menerima dan memahami materi mikrobiologi lebih memperhatikan makanan yang akan dikonsumsi. Hal senada juga diungkapkan pada penelitian mengenai hubungan antara pengetahuan Perilaku Hidup Bersih dan Sehat (PHBS) dengan pola hidup sehat oleh Banum (2016). Penelitian tersebut mengungkapkan bahwa nilai pengetahuan PHBS yang tinggi berkorelasi dengan tingginya nilai pola hidup sehat, demikian pula sebaliknya.

Pada penelitian ini, perilaku yang diamati adalah perilaku hidup bersih dan sehat (PHBS) yang dikaitkan dengan pengetahuan memilih makanan pada siswa. Pemilihan makanan merupakan suatu bentuk perwujudan sebuah tindakan perilaku makan seseorang dalam proses berpikir, berpengetahuan dan berpandangan tentang makanan. Hal ini sehubungan dengan adanya materi pada sistem pencernaan yang juga membahas mengenai gangguan yang bisa terjadi karena pola makan yang kurang seimbang, tidak teratur, stres, infeksi parasit serta gangguan lambung (Ashari dan Yuniar, 2016). Penelitian ini bertujuan untuk mengetahui kaitan antara tingkat 
pemahaman siswa kelas XI IPA SMA pada materi sistem pencernaan terhadap PHBS, khususnya perilaku pemilihan makanan.

\section{METODE}

Penelitian ini menggunakan pendekatan kuantitaif dan jenis penelitian korelasi. Populasi meliputi seluruh siswa kelas XI IPA SMAN 3 Jember berjumlah 210 siswa, dengan sampel 138 siswa yang ditentukan dengan cara random sampling. Jumlah sampel ditentukan dengan rumus Slovin dengan rumus sebagai berikut:

Keterangan:

$$
S=\frac{N}{N \cdot d^{2}+1}
$$

$S=$ Ukuran Sampel

$\mathrm{N}=$ Ukuran populasi

$\mathrm{d}=$ taraf signifikan yang dikehendaki

(Sugiyono, 2016).

Instrumen pengumpulan data menggunakan tes, angket dan dokumentasi. Tingkat pemahaman diperoleh dari nilai tes dengan kategori mengikuti Tabel 1.

Tabel 1. Kategori Penilaian Tingkat Pemahaman Materi Sistem Pencernaan

\begin{tabular}{ccc}
\hline No. & Nilai & Kategori \\
\hline$(1)$ & $(2)$ & $(3)$ \\
\hline 1. & Nilai $<76$ & D (Kurang) \\
2. & Nilai $<79$ & C (Cukup) \\
3. & Nilai $<87$ & B (Baik) \\
4. & Nilai $>87$ & A ( Sangat Baik)
\end{tabular}

Sumber: Data Sekolah (2019)

Sedangkan angket yang diberikan kepada siswa digunakan untuk mengukur perilaku pemilihan makanan. Jenis angket yang digunakan yaitu angket tertutup berisi 10 pertanyaan dengan menggunakan skala likert (5 skala).
Klasifikasi angket perilaku pemilihan makanan dengan indikator pengetahuan, sikap dan tindakan pemilihan makanan, dikategorikan mengikuti Tabel 2.

Tabel 2. Kategori Penilaian Jumlah Skor Angket Perilaku Pemilihan Makanan

\begin{tabular}{ccc}
\hline No. & Jumlah Skor & Kategori \\
\hline$(1)$ & $(2)$ & $(3)$ \\
\hline 1. & $11-20$ & Sangat Rendah \\
2. & $21-29$ & Rendah \\
3. & $30-38$ & Sedang \\
4. & $39-47$ & Kuat \\
5. & $48-55$ & Sangat Kuat \\
\hline
\end{tabular}

Sumber: Data diolah (Umar, 2001)

Teknik analisis data menggunakan uji korelasi pearson product moment pada aplikasi SPSS 22 dengan dasar pengambilan keputusan jika nilai signifikansi < 0,05 maka terdapat korelasi antar variabel. Penentuan tingkat keeratan hubungan antar variabel menggunakan Tabel 3, tingkatan keeratan hubungan.

Tabel 3. Tingkat Keeratan Hubungan

\begin{tabular}{cc}
\hline Interval & Tingkat Hubungan \\
\hline$(1)$ & $(2)$ \\
\hline $0,00-0,199$ & Sangat Rendah \\
$0,20-0,399$ & Rendah \\
$0,40-0,599$ & Sedang \\
$0,60-0,799$ & Kuat \\
$0,80-1,000$ & Sangat Kuat \\
Sumber: Sugiyono (2016)
\end{tabular}

\section{HASIL DAN PEMBAHASAN}

Dari hasil penelitian yang telah dilakukan terhadap 138 sampel siswa Kelas XI SMAN 3 Jember. Tingkat pemahaman materi sistem pencernaan yang diperoleh dari hasil tes pemahaman materi, disajikan melalui diagram pada gambar 1 . 
Berdasarkan Gambar 1, diketahui bahwa pemahaman siswa terhadap materi sistem pencernaan mayoritas tergolong baik, yaitu $92 \%$ atau sejumlah 129 siswa, sementara 6,5\% tergolong sangat baik dan 1,4\% tergolong cukup. terdapat 3 indikator utama untuk mengetahui perilaku pemilihan makanan, yaitu aspek pengetahuan, aspek sikap dan aspek tindakan yang dituangkan kedalam butir-butir pertanyaan.

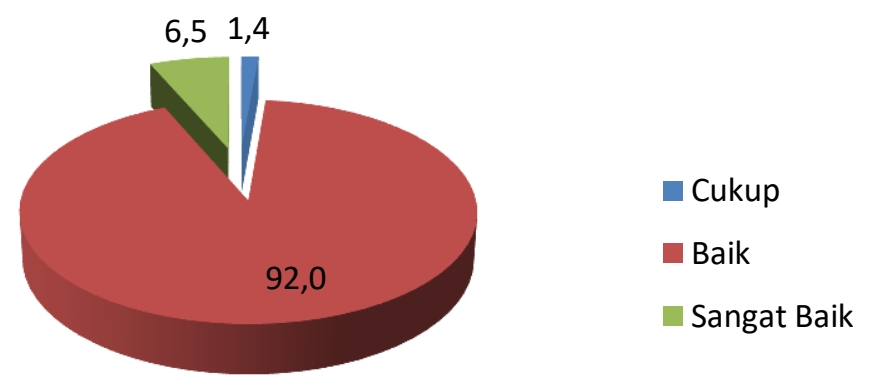

\section{Gambar 1. Tingkatan Pemahaman Materi Sstem Pencernaan}

Hal ini menunjukkan bahwa siswa cukup memahami tentang materi sistem pencernaan berdasarkan hasil posttest. Siswa dapat memenuhi indikator capaian pembelajaran yang ditetapkan oleh guru.

Hasil rekapitulasi angket yang diberikan tentang perilaku pemilihan makanan pada siswa dapat dilihat pada Gambar 2.
Berdasarkan hasil rekapitulasi angket, 86,2\% siswa masih memilih makanan apa yang seharusnya dikonsumsi dan tidak. Hal-hal yang menjadi pertimbangan siswa dalam memilih makanan yaitu pengetahuan terhadap kandungan makanan, kesukaan terhadap makanan, sikap terhadap keadaan makanan yang akan dikonsumsi serta perilaku mengkonsumsi.

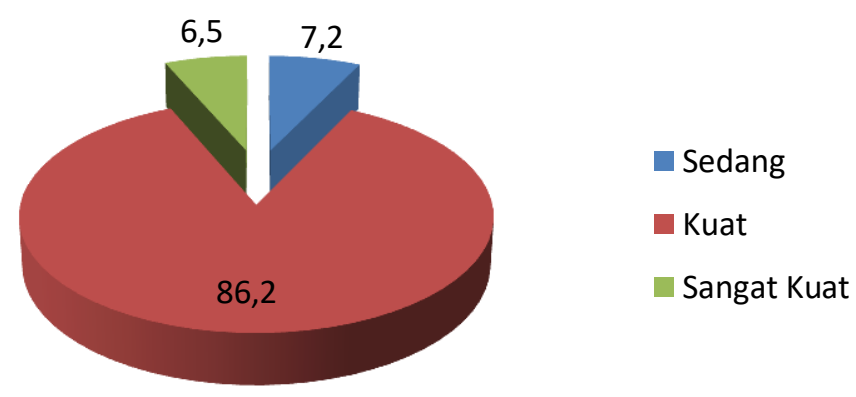

Gambar 2. Perilaku Pemilihan Makanan Siswa

Berdasarkan Gambar 2, diketahui bahwa perilaku pemilihan makanan pada siswa mayoritas tergolong kuat, yaitu 86,2\% atau sejumlah 119 siswa. Pada angket yang diberikan pada siswa
Hal ini sesuai dengan penelitian yang dilakukan oleh Banum (2016) mengenai hubungan antara pengetahuan Perilaku Hidup Bersih dan Sehat (PHBS) dengan pola hidup sehat yang juga menun- 
jukkan hubungan positif rendah. Penelitian lain yang juga mendukung hasil penelitian ini yaitu penelitian yang dilakukan oleh Febriyanto (2016) yang menunjukkan ada hubungan antara pengetahuan dan perilaku konsumsi jajanan.

Selanjutnya dilakukan uji hipotesis untuk mengetahui korelasi antara tingkat pemahaman siswa pada materi sistem pencernaan terhadap perilaku pemilihan makanan pada siswa. Data diuji dengan menggunakan uji Pearson Product Moment. Hasil uji Pearson Product Moment disajikan pada tabel 4.

Tabel 4. Hasil Uji Korelasi Pearson Product Moment

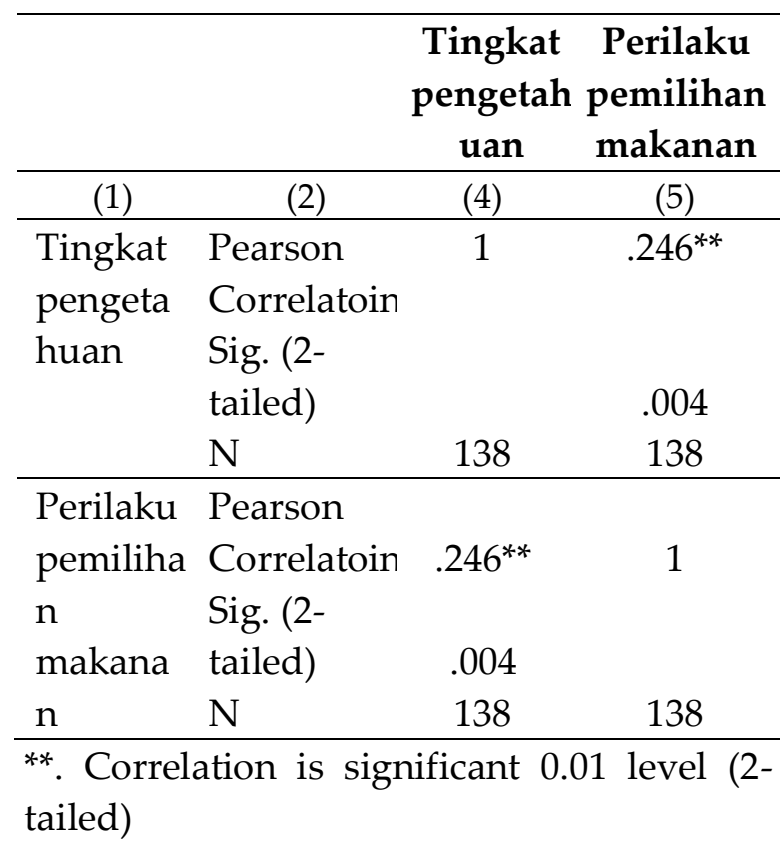

Hasil perhitungan menunjukkan nilai signifikan 0,004 <0,05, sehingga Ha dapat diterima dan Ho ditolak. Hal ini menunjukkan adanya hubungan antara tingkat pemahaman materi sistem pencernaan dengan perilaku pemilihan makanan dan bersifat positif. Keeratan antara kedua variabel hasil uji korelasi tingkat pemahaman materi sistem pencernaan dengan perilaku pemilihan makanan adalah 0,246 yang terletak pada 0,20 - 0,399 dengan arti bahwa keeratan hubungan antara dua variable tersebut adalah "rendah".

Pengetahuan merupakan suatu hal yang penting dalam sebuah proses pembentukan sebuah perilaku. Perilaku adalah segala bentuk kegiatan yang dilakukan seseorang yang secara langsung dapat diamati dalam melaksanakan tugas, fungsi dan peranannya (Nawi, 2017). Perilaku terbentuk karena sebuah pengetahuan yang didapat oleh seseorang baik dari sebuah informasi dari seorang guru, pengalaman, buku dan lain sebagainya. Azwar (2011) menyatakan bahwa pengetahuan seseorang akan sesuatu hal mempengaruhi sikap dari seseorang tersebut, sikap positif maupun negatif. Sehingga sikap yang dimiliki dari suatu pengetahuan itu akan tercermin dalam sebuah perilaku tertentu.

Pengetahuan yang dimaksud dalam penelitian ini ialah pengetahuan tentang materi sistem pencernaan yang didalamnya membahas berbagai macam sub bab antara lain organ pencernaan, kandungan zat gizi pada makanan, pencernaan hewan ruminansia dan penyakit atau kelainan pada sistem pencernaan. Pada sub-bab kelainan pada sistem pencernaan dibahas mengenai alasan terjadinya sebuah kelainan tersebut. Beberapa penyakit/ kelainan pada sistem pencernaan yang terjadi diakibatkan oleh makanan dan pola makan sehingga seseorang harus dituntut memiliki perilaku pemilihan makanan yang baik agar terhindar dari kelainan/penyakit pada sistem pencernaan. 
Hasil observasi pada perilaku harian sampel siswa kelas XI IPA SMA Negeri 3 Jember menunjukkan bahwa beberapa siswa membawa bekal makan dan minum ke sekolah, namun juga banyak dari mereka yang memilih untuk membeli makan dikantin dan diarea sekolah. Preferensi siswa yang membeli jajanan di kantin memilih jajajan seperti gorengan membeli mie instan dan juga cilok. Jenis makanan tersebut meru-pakan beberapa jenis makanan tidak sehat yang bila dikonsumsi secara rutin dapat membahayakan kesehatan siswa.

Menurut Notoadmodjo (2011) tingkat pengetahuan di dalam suatu domain kognitif ada 6 tingkatan, yaitu tahu, memahami, aplikasi, analisis, sintetis, evaluasi. Hasil penelitian ini membuktikan bahwa pengetahuan yang dimiliki oleh siswa masih berada pada tingkatan yang pertama yaitu pada tingkatan tahu, dan berkorelasi terhadap perilaku pemilihan makanan siswa. Rendahnya tingkat hubungan antara dua variabel tersebut juga dapat dipengaruhi oleh beberapa faktor eksternal lain seperti kebiasaan, adat istiadat, kepercayaan, sosial ekonomi dan lain-lain (Effendi, 1998).

\section{SIMPULAN}

Berdasarkan hasil penelitian, diperoleh kesimpulan bahwa ada korelasi antara tingkat pemahaman siswa pada materi sistem pencernaan terhadap perilaku pemilihan makanan dengan tingkat keeratan rendah.

\section{DAFTAR PUSTAKA}

Ashari dan Yuniar, A. Y. (2016). Implementasi
Backpropagation dan Forward Chaining dalam Mendiagnosa Penyakit Pencernaan dengan Pengobatan Cara Herbal. Jurnal Inspiration. Vol 6. No 2. 148-156. DOI:

http://dx.doi.org/10.35585/inspir.v6 $\underline{\text { i2. } 2424}$

Azwar, Syaifuddin. (2011). Sikap Manusia: Teori dan Pengukurannya. Yogyakarta: Pustaka Pelajar.

Banum, Titi Sari. (2016). Hubungan Antara Pengetahuan PHBS (Perilaku Hidup Bersih dan Sehat) dengan pola hidup sehat siswa di SD Negeri Tamanan Bantul TA2015/2016. Skripsi. Yogyakarta: Universitas Negeri Yogyakarta.

Chalik, Raimundus. (2016). Anatomi Fisiologi Manusia, Jakarta: Pusdik SDM Kesehatan.

Dodge, D. T, Colker, L. J. and Heroman, C. (2004). The Creative Curriculum for Preschool ( $4^{\text {th }}$ ed). Washington: D.C: Teaching Strategies, Inc.

Efendi, Nasrul. (1998). Dasar-dasar Keperawatan Kesehatan Masyarakat. Jakarta: EGC

Febriyanto, Mukhammad Aminudin Bagus. (2016). Hubungan antara Pengetahuan dan Sikap dengan Perilaku Konsumsi Jajanan Sehat di MI Sulaimanah Mojoagung Jombang. Skripsi. Surabaya: Universitas Airlangga

Hanum, Yuspa. (2016). Dampak Bahaya Makanan Gorengan Bagi Jantung. Jurnal Keluarga Sehat Sejahtera Vol. 14 (28): 103-114. DOI: 
Indonesian Journal of Mathematics and Natural Science Education, 1 (2), 2020

Lina Nur Amalina, Rosita Fitrab Dewi

https://doi.org/10.24114/jkss.v14i28 .4700

Hasmiati, Syamsudduha dan Jamilah. (2016). Hubungan antara Pengetahuan Mikrobiologi dengan Sikap Higienis Mahasiswa Pendidikan Biologi Angkatan 2013 Fakultas Tarbiyah dan Ilmu Keguruan UIN Alauddin Makassar. Jurnal Biotek Vol 4 (2). 231-243.

DOI: https://doi.org/10.24252/jb.v4i2.179 $\underline{5}$

Makhmudah, Siti. (2016). Revolusi Mental dalam Mengubah Pola Pikir Tenaga Pendidik dari Segi Perspektif Islam. Jurnal Education Vol. 2 (1): 86-91. DOI: https://doi.org/10.29210/12016237.

Nawi, Rusdin. (2017). Perilaku Kebijakan Organisasi. Makasar: CV Sah Media.

Notoatmodjo, Spekidjo. (2011). Pendidikan dan Perilaku Kesehatan. Jakarta: Rineka Cipta.

Priyanto, Agus dan Sri Lestari. (2008). Endoskopi Gatrointestinal. Jakarta: Salemba Medika.
Shaffer, D. R. and Kipp, K. (2010) Developmental Psychology Childhood $\mathcal{E}$ Adolescence. Georgia: Cengage Learing.

Sugiyono. (2016). Metode Penelitian Kuantitatif, Kualitatif dan RED. Bandung: Alfabeta

Umar, Husein. (2001). Riset Pemasaran dan Perilaku Konsumen. Jakarta: PT.Gramedia Pustaka.

\section{PROFIL SINGKAT}

Lina Nur Amalina, guru IPA di MTs Raudhatul Ulum Jl. Raya Gatot Kaca No. 1 Pringgondani, Bantur, Malang. Menempuh pendidikan S1 Tadris Biologi di Fakultas Tarbiyah dan Ilmu Keguruan Institut Agama Islam Negeri Jember dari tahun 2015 - 2019.

Rosita Fitrah Dewi, Dosen Tadris Biologi Fakultas Tarbiyah dan Ilmu Keguruan Institut Agama Islam Negeri Jember sejak tahun 2016 hingga sekarang. Riwayat pendidikan program sarjana S1 di Prodi Pendidikan Biologi Universitas Jember, pendidikan magister (S2) Biologi Universitas Jember. 